\title{
It's a Hard-Knock Life: Child Labor Practices and Compliance with IMF Agreements
}

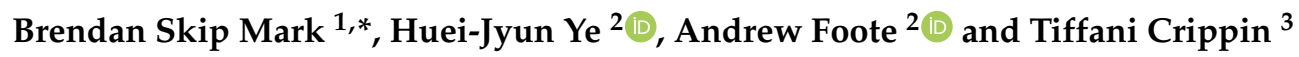 \\ 1 Department of Political Science, University of Rhode Island, Providence, RI 02881, USA \\ 2 Department of Political Science, Binghamton University, Binghamton, NY 13902, USA; \\ hye5@binghamton.edu (H.-J.Y.); afoote1@binghamton.edu (A.F.) \\ 3 GAIA Vaccine Foundation, Providence, RI 02909, USA; tcrippi1@binghamton.edu \\ * Correspondence: skipmark@uri.edu
}

check for updates

Citation: Mark, Brendan Skip, Huei-Jyun Ye, Andrew Foote, and Tiffani Crippin. 2021. It's a Hard-Knock Life: Child Labor Practices and Compliance with IMF Agreements. Social Sciences 10: 171. https://doi.org/10.3390/ socsci10050171

Academic Editor: M. Rodwan Abouharb

Received: 12 March 2021

Accepted: 2 May 2021

Published: 14 May 2021

Publisher's Note: MDPI stays neutral with regard to jurisdictional claims in published maps and institutional affiliations.

Copyright: (c) 2021 by the authors. Licensee MDPI, Basel, Switzerland. This article is an open access article distributed under the terms and conditions of the Creative Commons Attribution (CC BY) license (https:/ / creativecommons.org/licenses/by/ $4.0 /)$.

\begin{abstract}
How does IMF lending impact child labor? We argue that, as compliance with IMF reforms increases, child labor increases. IMF loans can help governments avoid bankruptcy, prevent debt defaults, and credibly signal a commitment to pro-market reforms which should generate trade and investment. However, IMF policies associated with revenue and social policies can have negative impacts on child labor. Education reforms undermine the quality of schooling, making child labor more likely. Healthcare reforms undermine the quality of healthcare; when parents are ill or injured, their children are more likely to enter the workforce to make up for lost income. Similarly, social safety net reforms reduce the ability of families to access a safety net during times of hardship and make it more likely that children are pushed into the labor market to keep families afloat. To test our argument, we use a control function selection model on a sample of 70 IMF borrowers between 2002 and 2016. Using new datasets on IMF compliance and child labor, we find that increased compliance with IMF reforms worsens child labor practices. Revenue and social policy compliance in particular are associated with an increase in child labor.
\end{abstract}

Keywords: child labor; IMF; austerity; reform; compliance; International Organizations

\section{Introduction}

The International Labor Organization (ILO) estimates that around 152 million children worldwide are involved in child labor and 70 million work in hazardous conditions (International Labor Organization 2017, p. 23). Poverty pushes children into the workforce to help supplement familial income, and a lack of familial support or work options pushes children into even more hazardous jobs. Businesses, then, hire child workers at a lower wage than adult workers, which helps maximize profits.

Although many international organizations (IOs), intergovernmental organizations (IGOs), and Western countries have worked hard for decades to eliminate child labor around the world, many countries with poor child labor records have strong incentives to hide their child labor practices from the international community (Hafner-Burton and Tsutsui 2005; Neumayer 2005). For this reason, it can be difficult to know exactly how widespread child labor is, and with limited monitoring capacity in sovereign countries, most IOs and IGOs struggle to have a meaningful impact on child labor. ${ }^{1}$

Differently, the International Monetary Fund (IMF 2020) and World Bank (World Bank 2020) have the opportunity to more directly monitor, and therefore impact, child labor practices in other countries. When the IMF or the World Bank enter into agreements with countries, they create a contract between themselves and the recipient government that outlines the exchange of loans or aid for a package of specific policy changes that should promote economic development through increased trade and foreign investment. Both the IMF and the World Bank directly monitor government compliance with conditions and can remove funding where there is noncompliance. Unfortunately, the focus of these 
reforms may have the unintended consequence of increasing child labor: as spending cuts and social welfare policy reforms push families further into poverty, more children must enter the labor force to help their families make ends meet.

In this project, we focus on the effect of compliance with IMF reform on child labor practices. We do this, in part, because the sources of the poor outcomes from IMF reforms are still heavily debated. Some scholars argue that the policies themselves are to blame, while others blame borrowers' low compliance with the necessary but difficult reforms (Dreher 2006, p. 781; Jensen 2004). With data on IMF compliance largely missing, few scholars have tried to test the direct effects of IMF reforms.

We use the State-level Compliance with IMF Programs (SCIP) developed by Mark to directly examine the relationship between IMF compliance and child labor (Mark 2018). The SCIP data not only contain recipient governments' overall compliance with IMF policies but also capture whether a government has complied with social or revenue policies. This data structure allows us to test the types of IMF reforms that affect child labor. Further, we use the child labor practices variable from the new WorkR2 dataset indicating whether a country has child labor in a given year (Cingranelli and Mark 2021). Our sample covers 77 IMF borrowers from 2002 to 2016. The empirical results support our hypothesis that the spending cuts and social welfare reforms required by the IMF deteriorate child labor practices. Countries that comply with more social and revenue IMF reforms are more likely to experience widespread child labor than borrowing countries that do not comply with these reforms, which suggests that these policies have a negative impact on child labor.

This project contributes to research on IMF programs and their impact on human rights. Although a large body of literature addresses how IMF reforms undermine the rights of citizens, workers, and minorities, not much attention has been paid to children's rights. Unlike the loud appeals for improving labor and minority rights, children's voices are largely unnoticed. This is not surprising given that children lack political, and oftentimes many other types of agency (Nolan 2011, pp. 43-44). Yet, children's lack of agency is one of the many reasons that they constitute a unique and important population for research. By studying the effect that policy change has on children, we can examine the relationship between a government and its disenfranchised, but still economically integrated, populations. While children are undoubtedly the largest population of disenfranchised but economically active citizens, governments serve many other populations who fit this description as well, such as prisoners, undocumented migrants, and mentally handicapped people. By focusing on children, this project is one of the first to explicitly examine how disenfranchised, economically active populations are impacted by IMF reform.

\section{IMF Reform, Economic Development, and Human Rights}

The IMF bails out countries facing economic crises by providing access to money in exchange for economic reforms. In the short term, IMF loans prevent bankruptcy and keep leaders from defaulting on their international and domestic debts. In the long term, agreeing to the economic reforms imposed by IMF lending also allows leaders to publicly and credibly commit to pro-market reforms in the future, which should help generate much needed foreign direct investment and trade (Blanton et al. 2015; Simmons 2000; Tomz 2012).

IMF economic reforms are designed to shift power away from the government and toward market actors in order to address the structural problems in a country that undermine economic growth and development (Abouharb and Cingranelli 2007; Blanton et al. 2015; Vreeland 2002). These reforms contain a broad set of economic policies aimed at reducing government spending, privatizing state-owned enterprises, removing barriers to trade and capital mobility, and increasing labor market flexibility (Stiglitz 2002). The idea behind these reforms that economic liberalization has positive effects on a number of outcomes besides wealth (Frankel and Romer 1999; Sachs and Warner 1995; Salinas and Aksoy 2006; Vamvakidis 1999; Wacziarg and Welch 2008). Further, the IMF believes that improved institutions and infrastructure encourage economic activities among the private 
sectors, which in turn facilitate long-term prosperity (Boughton 2001; Camdessus 1996). Indeed, some studies find that long-term users of IMF loans are more likely to exhibit successful economic growth than short-term users, and countries that participate in IMF programs are less likely to experience financial crises (Bas and Stone 2014; Papi et al. 2015). Nevertheless, a large body of research contrarily concludes that IMF lending undermines growth and that structural reforms increase the probability of government crises (Barro and Lee 2005; Dreher 2006; Dreher and Gassebner 2012; Przeworski and Vreeland 2000; Stubbs et al. 2020; Vreeland 2002, 2003). In short, the research on IMF outcomes is mixed.

Under normal circumstances, governments committed to liberal economic policies are expected to establish social welfare programs to compensate citizens for their losses from market openness (Rodrik 2012; Ruggie 1982; Walter 2017). Programs, such as unemployment insurance and labor market programs, are created not only to redistribute wealth but also to gain public support for trade openness (Burgoon 2001; Hays et al. 2005). However, IMF conditions push governments to cut spending in order to reduce debts and deficits. Most governments under IMF programs opt to cut butter rather than guns, as security concerns often outweigh social welfare concerns. In Pakistan's case, although the country has repeatedly undergone IMF lending, its leaders have avoided cuts to security spending for fear of angering the military (Jorgie 2019). Instead, when under economic austerity, governments are more likely to make cuts to spending on policies associated with education, healthcare, and social safety nets.

Opening up trade while simultaneously cutting social welfare spending, reducing the resources used to monitor and punish labor violations, and decreasing domestic protections of workers produces greater violations of labor rights (Abouharb and Cingranelli 2007; Mosley 2000; Rudra 2008). Although IMF reforms focus on the long-term goals of economic growth, stability, and poverty reduction, in the short-term they weaken the regulatory capacity of states, undermine labor organizations, and increase the use of off-the-books and shadow sector employment (Blanton et al. 2018; Clements et al. 2013; Rickard and Caraway 2019; Stubbs and Kentikelenis 2018). Perhaps unsurprisingly, while businesses benefit from privatization and labor market deregulation, everyday citizens often end up paying the costs for IMF reform.

There is a large body of literature showing IMF reforms increase hardships for the poor and increase poverty (Easterly 2000, 2003; Nooruddin and Simmons 2006; Abouharb and Cingranelli 2007; Nooruddin and Vreeland 2010; Oberdabernig 2013). Cuts to social welfare policies in particular harm the poor who are often the primary beneficiaries of social safety nets. These cuts also push individuals into poverty who were being held afloat by social welfare programs. Individuals who become unemployed due to shifts in the labor market are also more likely to fall into poverty as these programs are cut. The poor are politically weak and rarely mobilize to challenge the government; as a result, policy reforms which hurt the poor are politically preferable to policy reforms which hurt more politically powerful or organized groups (Nooruddin and Simmons 2006).

Previous work has also tied IMF reform to inequality, poor health and education outcomes, women's rights violations, and increased government repression (Abouharb and Cingranelli 2007, 2009; Detraz and Peksen 2016; Garuda 2000; Kentikelenis et al. 2015; Kentikelenis et al. 2016; Marphatia 2010; Oberdabernig 2013; Pion-Berlin 1983; Rowden 2008, 2013). For example, privatization tends to disproportionately affect women and minorities, who benefit from public employment and have a more difficult time finding employment under equal conditions in the private sector (Abouharb and Cingranelli 2007; Blanton et al. 2015; Detraz and Peksen 2016). These groups also face a higher rate of labor violations and are likely to experience a weakening of individual labor rights (Detraz and Peksen 2016; Reinsberg et al. 2019). Additionally, as IMF reforms often ask countries to create export processing zones (EPZs), which are exempt from domestic labor laws, labor rights violations are larger in EPZs than in non-EPZs (Abouharb and Cingranelli 2007). The negative effects of labor violations are further compounded by budget cuts to monitoring agencies, which leave them less able to identify and report labor rights 
violations (Abouharb and Cingranelli 2007; Mark 2018). The literature tying IMF reform to increased violations of labor rights is particularly large, yet the impact of IMF reform on child labor has been largely neglected (Abouharb and Cingranelli 2007; Blanton et al. 2015; Detraz and Peksen 2016; Martin and Brady 2007; Nooruddin and Vreeland 2010; Vreeland 2002).

\section{IMF Reform and Child Labor}

Poverty is a major cause of child labor (Ahmed 1999). The link between poverty and child labor has been confirmed through a variety of empirical specifications and is the foundation of most work on child labor today. ${ }^{2}$ One of the most direct tests of this relationship is an experiment in Ecuador where poor families were randomly assigned to receive a cash transfer of USD 15 a month (Edmonds and Schady 2012). The cash transfer led to a decrease in both paid labor and economic activities inside the home for children. Put simply, parents only send their children to work when they are too poor to do otherwise. Given the options, parents would prefer their children to attend schools or enjoy leisure time rather than to earn additional income for the household (Basu and Van 1998, p. 416).

We argue that the effects of IMF reforms will increase the incidence of child labor, as a weakened state will find it difficult to monitor child labor practices in the private sector. A common outcome of IMF programs is the deterioration of civil, political, and labor rights of citizens (Abouharb and Cingranelli 2007; Blanton et al. 2015; Reinsberg et al. 2019; Stubbs and Kentikelenis 2017, 2018). IMF reforms lead to cuts in public sector employment and reduce social welfare spending in democracies by so much that their budgets become indistinguishable from non-democracies (Nooruddin and Simmons 2006; Rickard and Caraway 2019). Without strong labor organizations, labor rights will deteriorate, including those of children, who are often the least protected, and an increase in informal sector employment puts child laborers at heightened risk of exploitation.

Additionally, the poor are affected by IMF reforms in two ways: first, the poor bear the bulk of the economic hardship from reforms because they are the least capable of accessing private substitutes for state-provided education and healthcare when those resources are cut; and second, when the effects of reforms create new economic opportunities, the poor are the least capable of seizing on those opportunities. ${ }^{3}$ As a result, we expect that increased compliance with reforms will impose greater economic hardship on impoverished households. When this happens, parents will have an urgent need to shift their children's activities from education to labor. ${ }^{4}$

IMF reforms can negatively impact education in a number of ways. Stubbs et al. found that, between 1990 and 2014, each additional condition attached to an IMF lending agreement decreased government education spending (Stubbs et al. 2020). IMF structural adjustment conditions can also affect employment in education. For example, reforms can call for cuts to education sector employment (Bulgaria in 2006 and Tajikistan in 2004), limits on teacher pay (Sierra Leone in 2002), or broad education reform (Armenia in 2019). Policies can also lead to education cuts through broad aims to control public sector spending, limit wage bills, and limit public employment. In order for parents to choose to educate their children through formal schooling, the long-term benefits of sending children to school must outweigh the immediate benefits of their labor; and, the benefits of education are directly tied to the quality of the schools educating children (Bass 2004; Guarcello et al. 2008). Previous research shows that "(w)hen [parents] observe an improvement in the learning achievements of their children, they increase their involvement in education by reducing their participation in economic activities (Rossi and Rosati 2007, p. 10)". However, where IMF reforms have deteriorated education quality, the long-term benefits of formal education are less clear and may not outweigh the benefits of child labor in the short term.

Finally, IMF reforms also increase child labor through policies that target healthcare. The reform processes that weaken healthcare are similar to those that weaken education: the IMF pushes policies that limit expenditure in health ministries (Burundi in 2012), cut the 
healthcare system at large (Colombia in 2003), and shift supplementary health insurance from the public sector to the private sector (Croatia in 2004). Privatization of health care and cuts to healthcare spending can decrease the effectiveness of the healthcare system. Studies have tied these IMF-led changes to deadly health outbreaks such as the spread of HIV / AIDS and tuberculosis in the developing world. ${ }^{5}$

There is also a strong and positive link between the size of the child population relative to the adult population and child labor (Admassie 2002, pp. 268-9). Adult disability and mortality may increase if adults do not have access to quality healthcare such as vaccines, treatment for disease and injury, information about family planning, etc. (Ahmed et al. 2012; Darroch et al. 2011; World Health Organization 2014). Where IMF reforms cut healthcare funding, workers find it more difficult to access quality healthcare when they become ill or injured. Without access to quality care, many illnesses and injuries can become debilitating. When a parent becomes too ill or injured to work, their child must begin working to make up for the loss of parental income. This link between IMF reforms and child labor can also have long-lasting effects even when IMF reforms have helped decrease poverty: high adult mortality rates resulting from poor access to healthcare can leave the country with a large number of orphans who have no choice but to work in order to provide for themselves.

The child is only spared from working if (1) the family has enough savings to get by, (2) the surviving parent finds a way to make additional income, or (3) the government has a welfare system in place to assist the family. These options are often unavailable to families living in countries that comply with IMF conditions, as they often ask governments to cut both welfare and healthcare spending.

High fertility rates also increase child labor: in order to support a new sibling, older children are sent to work to help increase household income. ${ }^{6}$ Indeed, research shows that older siblings are often removed from school and put to work due to the birth of a new sister or brother (Chernichovsky 1985; Dammert 2008; Edmonds 2007; Emerson and Souza 2008; Levison 1991; Morduch 2000). Access to family planning resources and contraceptives helps families limit unplanned pregnancies, but when IMF reforms cut access to healthcare services, these resources become less available, leading to higher fertility rates and therefore more child labor (Shenk et al. 2013).

Altogether, this suggests that, while IMF reforms aim to increase economic development and decrease poverty, they will have important consequences for child labor practices. Short-term increases in poverty will push children into the labor force to help supplement family income as social safety nets are cut; cuts to education spending will decrease education quality, which will encourage parents to send their children to work; decreased healthcare spending will exacerbate all of this by increasing the risk that parents are pulled from the labor force due to illness or injury and/or family sizes grow too large to be supported with only parental income.

Hypothesis 1. Greater compliance with IMF agreements will increase child labor.

\section{Research Design}

To test our argument, we use cross-sectional time-series data for a global sample of countries. The time-series component covers 2002-2016. This period is advantageous as it contributes to the debate about whether reforms to IMF lending agreements have ameliorated the negative human rights consequences that critics have levied against the IMF. Some scholars contend that reforms to IMF programs make them less harmful today than they were in the past (Grabel 2011). Others argue that reforms to IMF programs are largely ceremonial and do nothing to reduce the negative externalities associated with lending agreements (Kentikelenis et al. 2016). This sample allows us to test whether current IMF lending agreements undermine efforts to reduce child labor.

Our model focuses on IMF borrower countries. Thus, our sample consists of IMF borrower country-years. Since a country not under an IMF loan has missing scores for all compliance metrics, this design is most suitable for analyzing the available data. This is the 
approach taken by recent work exploring IMF loan design and its outcomes (Mark 2018; Rickard and Caraway 2019; Stubbs et al. 2020). Our model consists of 70 IMF borrowers between 2002 and 2016. ${ }^{7}$ One limitation of this approach is that it reduces our sample size, and small-sample maximum likelihood estimation increases the risk of type II errors (Gericke and Crippin 2017).

\subsection{Outcome Variable: Child Labor}

Our dependent variable is a dichotomous measure of child labor coded 1 if child labor occurs in a country and 0 if there is no child labor. Data are taken from the WorkR2 dataset, which codes U.S. State Department Annual Reports on Human Rights Practices for all countries of the world (Cingranelli and Mark 2021). Coding guidelines for this measure are taken from the Minimum Age Convention and Recommendation (C138, R146), the Worst Forms of Child Labour Convention and Recommendation (C182, R190), the Conditions of Employment of Younger Persons Recommendation (R125), and the Medical Examination of Young Persons (C077, C078, C124). This measure captures child labor that occurs outside of the home or family business, is exploitative or hazardous, and work that interferes with schooling. This measure covers the period from 1994-2017 for all countries of the world.

While other measures of child labor exist, such as those produced by the ILO or World Bank, these measures are missing for many country-years to the point of being ineffective for the study of dynamic processes. For example, the Understanding Children's Work Project, which combines available data from the ILO, World Bank, and UNICEF, only has a single country-year score for 70 countries in the 21 st century. The WorkR2 measure of child labor covers 4229 country-years and is available for all countries of the world. While this measure is blunt, it is a good fit because child labor is intentionally unknowable. This measure offers a general idea of the conditions within the country, which is often the best that we can do when the topic of interest is so difficult to observe.

\subsection{Covariates of Child Labor}

We argue that child labor is negatively affected by IMF compliance. We are interested in whether a country undergoing IMF lending has actually implemented the agreed-upon policies. While previous work has looked at the consequences of being under a loan, the time under a loan, or the number of conditions, this is one of the few papers to explore the consequences of compliance with IMF agreements (Mark 2018; Vreeland 2006). The data are taken from the State-level Compliance with IMF Programs (SCIP) Dataset developed by Mark (Mark 2018). These data code compliance with IMF policies using four of the IMF MONA datasets as well as using content analysis to recode text variables into numeric scores. We use the variables related to social policy compliance and revenue compliance. Social policies include conditions affecting education, healthcare, pensions and other social welfare policies. Revenue policies are conditions meant to alter revenue generation in the borrowing state. We include four measures of compliance. Two of the measures, "social policies met" and "revenue policies met", capture the number of conditions met in a year. We also include the percentages of social and revenue policies met, which are calculated as the number of policies met divided by the number of social policies the country was asked to meet. The SCIP data include all IMF loans between 2002 and 2019 and is the only dataset that codes compliance among different policy conditions attached to loans. Our expectation is that all four measures will be positively correlated with child labor. We opt for compliance among specific policies, as our theoretical argument specifically identifies social policies and spending as important causal mechanisms, we examine social and revenue policies in isolation.

Following previous research ${ }^{8}$, we include a number of control variables that are likely to affect both child labor and IMF compliance. We include trade as a percentage of gross domestic product (Trade) and foreign direct investment inflows (FDI). We use gross domestic product per capita (GDPPC) and include the population size of a country (Population). All four measures are taken from the World Bank's World Development 
Indicators and all four measures are logged. We include the Boix-Miller-Rosato (Boix et al. 2013) dichotomous measure of democracy (Democracy) as well as the magnitude of civil violence (Civil violence), which was taken from the Major Episodes of Political Violence dataset. Finally, we include regional fixed effects and a lagged dependent variable. ${ }^{9}$

\subsection{Methodological Approach}

Selection bias is a common concern in the study of IMF program outcomes (Abouharb and Cingranelli 2007; Stubbs et al. 2020; Vreeland 2003). Countries that are given IMF loans are non-random, as certain institutional and political characteristics make some countries more likely to undergo lending agreements than others. Factors which increase the chance of receiving (or complying with) an IMF loan may also be correlated with the determinants of child labor conditions. Failure to account for non-random selection would introduce bias to our estimates.

Our model specification has a large impact on whether we find evidence that selection bias is a problem. The results when using a two-stage model conditional mixed-process $(\mathrm{CMP})$ recursive estimator suggest that a selection model is unnecessary, yet a control function approach model ${ }^{10}$ suggests the need for one. As such, we present the control function model in the paper and include the CMP model and bivariate probit models in the Appendices A-I.

To test for non-random selection, we use a control function approach, which is a variant of the Heckman selection model. This approach is common in recent work that accounts for selection bias in IMF models (Ortiz and Béjar 2013; Rickard and Caraway 2019; Stubbs et al. 2020). The control function approach first estimates a selection equation predicting IMF participation using a random-effects logit model. The model generates an inverse-Mills ratio that is included as a covariate in the child labor outcome equation. Like the Heckman model, the control function approach requires an excludable instrument, which we discuss below. The inverse-Mills ratio (IMF selection) is significant in two out of the four models. This indicates that failure to account for IMF selection will bias our findings. We opt to include the inverse-Mills ratio in all four models, though our findings are unchanged if we exclude it where it is insignificant. ${ }^{11}$

In the selection equation, we control for several economic and political determinants of IMF lending decisions. Prior work ${ }^{12}$ has found economic distress to increase the likelihood of IMF participation (Abouharb and Cingranelli 2009). We, therefore, control for per capita gross domestic product (GDPPC), gross domestic product growth (GDP growth), population (Population), consumer price inflation as an annual percentage (Inflation), total reserves in US dollars (Reserves), foreign direct investment inflows (FDI), and trade as percentage of GDP (Trade). We include a dichotomous measure of democracy (Democracy), a dichotomous measure of OECD membership (OECD), and civil violence magnitude (Civil Violence) as political variables which impact who receives loans. We also include a year measure and a dichotomous indicator for pre- and post-global recession, as lending decisions have changed significantly in recent years due to the recession. Finally, we include the number of IMF borrowers and temporary membership in the UN Security Council as our excludable instruments. Neither is likely to affect child labor, but both should influence IMF lending decisions. The number of borrowers influences lending decisions because the IMF has a limited amount of resources it can give out; as the number of borrowers increases, the IMF can be more selective about who will receive loans. Temporary UN Security Council membership has been found to reduce the stringency of loan conditions due to the interference of politically powerful IMF member states when designing loans. ${ }^{13}$

To ensure the proper temporal order, we lag all independent variables one year. This approach allows us to comment specifically on the impact of IMF compliance in the previous year on child labor practices in the current year. We opt for this modeling specification to give compliance with IMF programs a full year to impact child labor practices through the causal mechanisms discussed in our theory. Without a lag, the model 
assumes that IMF compliance impacts child labor practices within the same year. Finally, we also cluster the standard errors by country.

\section{Results}

In Table 1, we present the results from the model predicting selection into an IMF program. This model is used to produce an inverse-Mills ratio that is included in the child labor outcome equation to control for selection bias. The sample consists of 137 countries for the period 2002-2016. Our findings are in line with past work on IMF program participation. We find that countries with economic problems are more likely to undergo IMF lending. Non-OECD countries, lower levels of FDI, and lower reserves are more likely to undergo lending. Large population countries and those with civil violence are more likely to undergo IMF lending. Our excludable instrument, the number of IMF borrowers is significant and positive indicating that as the number of countries under IMF lending increases a country is more likely to select into an IMF program.

Table 1. Random Effects Logit Model. DV: $0=$ Not Under IMF Lending $1=$ Under IMF Lending.

\begin{tabular}{lc}
\hline & Model 1 \\
\hline UN Security & -0.043 \\
OECD & $(0.472)$ \\
& $-2.060^{* * *}$ \\
GDP (log) & $(0.605)$ \\
Population (log) & -0.000 \\
& $(0.098)$ \\
FDI (log) & $0.373^{*}$ \\
Trade (log) & $(0.201)$ \\
Inflation & $-0.175^{* *}$ \\
Total reserves & $(0.089)$ \\
GDP growth & 0.164 \\
Civil violence & $(0.378)$ \\
Democracy & 0.006 \\
Number of IMF borrowers & $(0.016)$ \\
Year & $-0.000 *$ \\
Crisis (dichotomous) & $(0.000)$ \\
Constant & -0.018 \\
Observations & $(0.019)$ \\
Number of countries & $1.030 * * *$ \\
\hline Robust standard er & $(0.337)$ \\
& 0.422 \\
& $(0.420)$ \\
& $0.037 * * *$ \\
& $(0.009)$ \\
& 0.021 \\
& $(0.048)$ \\
& -0.090 \\
& $(0.373)$ \\
& -47.547 \\
& $(95.896)$ \\
& 1799 \\
& 137 \\
\hline
\end{tabular}

Robust standard errors clustered by country-year in parentheses. ${ }^{* * *} p<0.01,{ }^{* *} p<0.05,{ }^{*} p<0.1$.

Table 2 presents the findings from our main model. The inverse-Mills ratio variable (IMF selection) is significant in the first two models which suggests that the unobservable factors that affect selection into an IMF program are significantly related to child labor, this confirms that selection bias is an issue in these models. 
Table 2. Probit Model Results. DV: $0=$ No Child Labor $1=$ Child Labor.

\begin{tabular}{|c|c|c|c|c|}
\hline & Model 2 & Model 3 & Model 4 & Model 5 \\
\hline Social Policies Met & $\begin{array}{c}0.918^{* * *} \\
(0.194)\end{array}$ & & & \\
\hline Revenue Policies Met & & $\begin{array}{c}0.363^{* *} \\
(0.143)\end{array}$ & & \\
\hline Percent Social Policies Met & & & $\begin{array}{c}2.500 * * \\
(1.089)\end{array}$ & \\
\hline Percent Revenue Policies Met & & & & $\begin{array}{c}0.580 \\
(0.895)\end{array}$ \\
\hline GDP per capita (log) & $\begin{array}{l}-0.058 \\
(0.056)\end{array}$ & $\begin{array}{l}-0.074 \\
(0.054)\end{array}$ & $\begin{array}{c}0.382 \\
(0.265)\end{array}$ & $\begin{array}{c}0.029 \\
(0.054)\end{array}$ \\
\hline Population (log) & $\begin{array}{c}0.418^{* * *} \\
(0.135)\end{array}$ & $\begin{array}{c}0.507 * * * \\
(0.154)\end{array}$ & $\begin{array}{c}1.431 \\
(1.180)\end{array}$ & $\begin{array}{c}0.296 \\
(0.200)\end{array}$ \\
\hline FDI $(\log )$ & $\begin{array}{c}-0.639 * * * \\
(0.162)\end{array}$ & $\begin{array}{c}-0.672 * * * \\
(0.176)\end{array}$ & $\begin{array}{l}-2.541 \\
(1.708)\end{array}$ & $\begin{array}{c}-0.463 \text { ** } \\
(0.193)\end{array}$ \\
\hline Trade (log) & $\begin{array}{c}0.569 \\
(0.399)\end{array}$ & $\begin{array}{l}0.895 * \\
(0.470)\end{array}$ & $\begin{array}{c}5.312 \\
(3.607)\end{array}$ & $\begin{array}{c}0.351 \\
(0.543)\end{array}$ \\
\hline Democracy (Binary) & $\begin{array}{c}0.248 \\
(0.346)\end{array}$ & $\begin{array}{c}0.303 \\
(0.359)\end{array}$ & $\begin{array}{c}2.376^{* *} \\
(1.058)\end{array}$ & $\begin{array}{c}-0.065 \\
(0.369)\end{array}$ \\
\hline Civil violence & $\begin{array}{c}0.665^{* *} \\
(0.300)\end{array}$ & $\begin{array}{c}0.819^{* *} \\
(0.336)\end{array}$ & OMITTED & OMITTED \\
\hline IMF selection & $\begin{array}{c}-3.159 * \\
(1.736)\end{array}$ & $\begin{array}{c}-3.577^{*} \\
(1.863)\end{array}$ & $\begin{array}{l}-15.893 \\
(10.173)\end{array}$ & $\begin{array}{l}-2.096 \\
(2.867)\end{array}$ \\
\hline Lagged DV & $\begin{array}{c}1.368^{* * *} \\
(0.310)\end{array}$ & $\begin{array}{c}1.093 * * * \\
(0.304)\end{array}$ & $\begin{array}{c}2.466 \\
(1.554)\end{array}$ & $\begin{array}{c}1.891^{* * * *} \\
(0.475)\end{array}$ \\
\hline Constant & $\begin{array}{c}7.189 * * \\
(3.529)\end{array}$ & $\begin{array}{c}5.640 \\
(3.573)\end{array}$ & $\begin{array}{l}-0.500 \\
(7.339)\end{array}$ & $\begin{array}{c}3.414 \\
(4.454)\end{array}$ \\
\hline Observations & 422 & 422 & 72 & 310 \\
\hline Region fixed effects & YES & YES & YES & YES \\
\hline
\end{tabular}

Robust standard errors in parentheses. ${ }^{* *} p<0.01,{ }^{* *} p<0.05,{ }^{*} p<0.1$.

Turning to our outcome variables of interest, we find support for our hypothesis. As countries implement more IMF social and revenue policies, they are more likely to have worse child labor practices. In model 2, social policies met is statistically significant and positively related to child labor. In our sample, countries meet between 0 and 4 policies in a given year; if a country implements four policies in a year, they are 7\% more likely to see child labor in their country. Model 4 also finds that the percent of social policies met is statistically significant. If a country implemented $100 \%$ of the social policies it was asked to meet, our model predicts that the country would be $14 \%$ more likely to see child labor in the country. The number of revenue policies met is also statistically significant and positively associated with child labor. In our sample, the number of revenue policies met ranges from 0 to 11 . If a country implemented 11 policies, we would see a $10 \%$ increase in the probability of seeing child labor in the country. In model 5 , percent of revenue policies met is not significant. These substantive effects are shown below in Figure 1.

Figure 1 shows out-of-sample predictions for each of the main variables of interest on child labor practices. Figure 1A shows the relationship between the number of IMF social policies implemented and child labor; Figure 1B shows the relationship between the number of IMF revenue policies implemented and child labor; and Figure 1C show the relationship between the percent of IMF social policies implemented and child labor.

In general, the control variables behave as expected. The findings for FDI and trade suggest that the relationship between economic liberalization and child labor is complex and behaves in ways consistent with the labor rights literature. ${ }^{14}$ As shown in models 2, 3 , and 5, the increase in FDI reduces the chances of hiring child labor. This could be that the capital inflows improve the economic conditions so that children do not need to serve as the main source of livelihood. Moreover, multinational companies will face greater market pressure and moral condemnation if they are found to employ child laborers in the 
workforce. Thus, foreign investment may decrease child labor. However, we do not rule out the possibility that some foreign firms invest in developing countries specifically to take advantage of cheaper and less regulated labor. Nike, an American-based multinational corporation with factories in many developing countries, has been the target of widespread international shaming, boycotts, and divestment campaigns for child labor in its factories (Boggan 2001). Similar examples imply that modeling FDI and trade merely by volume might be insufficient. Rather, the industries that the FDI invests in or the IMF programs reform may play a crucial role in the child labor situations. If governments under IMF lending emphasize the development of labor-intensive industries, their top priority may be to expand the available labor force rather than to protect child labor.
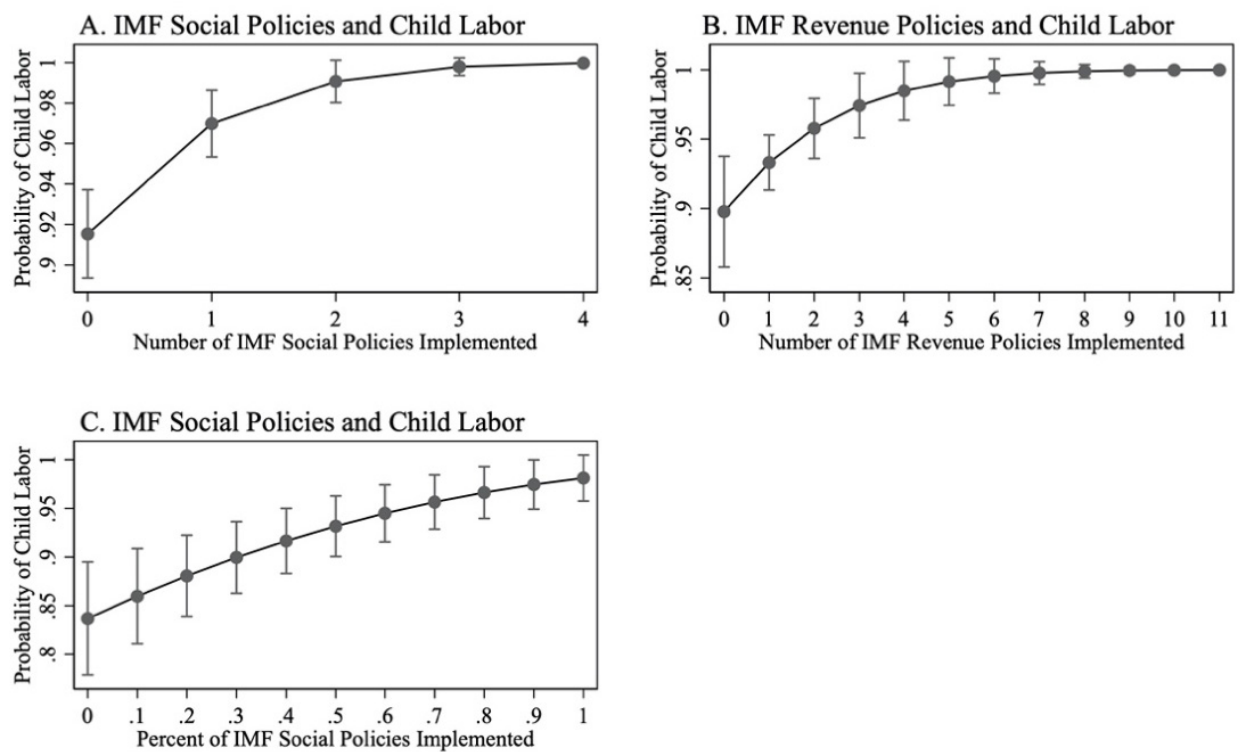

Figure 1. IMF Compliance and child labor predictions 95\% CI.

We run a number of robustness models which can be found in Appendices A-I. Our findings are largely unchanged regardless of model specification..$^{15}$ Overall, our empirical findings lend strong support to our argument that social policies and revenue policies implemented under IMF lending are associated with an increase in child labor.

\section{Conclusions}

In the models above, we find that compliance with IMF social and revenue policies contributes to a worsening of child labor practices. This finding alone suggests that the currently advocated reform strategies must be re-examined to account for the possible consequences for children. While reform advocates have long agreed that there are undoubtedly costs to these types of policy changes, few have acknowledged the costs that are paid by children (Hellman 1998). The effect of reform on child labor is especially important given the long-lasting impact it has on development. Where reforms lead to an increase in child labor, they will also lead to a decrease in education, as children only have so many hours in the day to dedicate to each activity; and where reforms lead to decreases in children's engagement with education, they deplete future human capital, a long-known determinant of economic development (Schultz 1960, 1961).

It is unclear whether the future benefits of IMF reform, namely increases in trade and foreign investment, will lead to decreases in child labor in the future. Indeed, there is reason to suspect that increased trade in low-skill sectors may increase child labor even further. As the producers of over $70 \%$ of the world's cocoa beans, West African cocoa farms enjoy consistent levels of trade, yet these farms are well-known for employing children (Whoriskey et al. 2019). Since children constitute a relatively healthy, cheap labor force, convincing firms to remove them from the workforce is difficult, especially where reform 
has also cut funding to labor rights monitoring. This project offers a starting point for many future projects to explore both the short-term and possible long-term consequences of IMF reform on child labor and children's livelihoods more generally.

The literature on IMF conditionality and labor rights has largely focused on collective labor rights ${ }^{16}$ or wage levels ${ }^{17}$, yet there are a large number of individual labor rights that have not been explored. We hope that this paper will help push researchers to explore other avenues of individual labor rights such as occupational health and safety, forced labor, minimum wages, and limitations on work hours. There are clear connections between each of these rights and the policy consequences outlined in this paper and the literature on IMF and labor rights that are worth exploring.

By turning our focus to child labor, this project not only adds to the existent research on how IMF programs increase labor rights violations in recipient countries but also introduces a new avenue of research which has been largely neglected in the human rights literature. As a group without much political or economic agency, children have rarely received attention in social science research or in research on the consequences of IMF reform. The study of child labor and children's rights is one of the least contentious human rights issues, as there is near universal support for improving children's rights. Despite this, children are often forgotten or left behind when adults make public policy. The findings here suggest that economic policy reforms need to incorporate protections for children. The IMF appears to be undermining the global effort to reduce child labor and should reform its lending conditions and monitoring of borrower countries to ameliorate the negative human rights consequences of program lending.

Author Contributions: Conceptualization, T.C., B.S.M., H.-J.Y. and A.F.; Methodology, T.C. and B.S.M.; Formal Analysis, T.C., B.S.M., H.-J.Y. and A.F.; Data Curation, T.C. and B.S.M.; WritingOriginal Draft Preparation, T.C., B.S.M., H.-J.Y. and A.F.; Writing—Review \& Editing, T.C., B.S.M., H.-J.Y. and A.F. All authors have read and agreed to the published version of the manuscript.

Funding: This research received no external funding.

Conflicts of Interest: The authors declare no conflict of interest.

Appendix A. Descriptive Statistics

\begin{tabular}{|c|c|c|c|c|c|}
\hline Variable & Observations & Mean & SD & Min & Max \\
\hline Child labor & 1750 & 0.76 & 0.42 & 0 & 1 \\
\hline Civil violence & 1686 & 0.08 & 0.51 & 0 & 4 \\
\hline Crisis & 1796 & 0.62 & 0.49 & 0 & 1 \\
\hline Democracy & 1686 & 0.64 & 0.48 & 0 & 1 \\
\hline FDI (logged) & 1621 & 20.96 & 2.35 & 10.36 & 27.32 \\
\hline GDP per capita (logged) & 1685 & 27.37 & 2.82 & 20.43 & 36.98 \\
\hline Inflation & 1770 & 5.51 & 7.15 & -35.84 & 109.68 \\
\hline Number of IMF borrowers & 1796 & 44.52 & 10.36 & 38 & 66 \\
\hline OECD & 1796 & 0.24 & 0.43 & 0 & 1 \\
\hline Population (logged) & 1686 & 16.09 & 1.57 & 13.01 & 21.04 \\
\hline Reserves & 1678 & $5.63 \times 10^{10}$ & $2.51 \times 10^{11}$ & $7,376,739$ & $3.90 \times 10^{12}$ \\
\hline Revenue compliance & 377 & 0.26 & 0.26 & 0 & 1 \\
\hline Revenue policies met & 489 & 1.18 & 1.66 & 0 & 11 \\
\hline Social compliance & 125 & 0.26 & 0.36 & 0 & 1 \\
\hline Social policies met & 489 & 0.15 & 0.45 & 0 & 4 \\
\hline Trade (logged) & 1677 & 4.33 & 0.66 & -1.79 & 6.09 \\
\hline UN security & 1796 & 0.06 & 0.24 & 0 & 1 \\
\hline Unique revenue conditions & 460 & 6.76 & 6.36 & 0 & 38 \\
\hline Unique social conditions & 460 & 0.90 & 1.54 & 0 & 8 \\
\hline
\end{tabular}


Appendix B. Lagged Dependent Variable No Selection Control

\begin{tabular}{|c|c|c|c|c|}
\hline \multirow[b]{2}{*}{ Probit } & \multicolumn{4}{|c|}{ Child Labor } \\
\hline & 1 & 2 & 3 & 4 \\
\hline Lagged DV & $\begin{array}{c}1.466^{* * *} \\
(0.327)\end{array}$ & $\begin{array}{c}1.253 * * * \\
(0.337)\end{array}$ & $\begin{array}{c}2.132 * * * \\
(0.799)\end{array}$ & $\begin{array}{c}1.965^{* * *} \\
(0.470)\end{array}$ \\
\hline Social Policies Met & $\begin{array}{c}0.745^{* * *} \\
(0.212)\end{array}$ & & & \\
\hline Revenue Policies Met & & $\begin{array}{c}0.298^{* * *} \\
(0.113)\end{array}$ & & \\
\hline Social Compliance & & & $\begin{array}{c}1.886^{* * *} \\
(0.699)\end{array}$ & \\
\hline Revenue Compliance & & & & $\begin{array}{c}0.575 \\
(0.853)\end{array}$ \\
\hline GDP (log) & $\begin{array}{l}-0.079 \\
(0.050)\end{array}$ & $\begin{array}{c}-0.093 * \\
(0.050)\end{array}$ & $\begin{array}{c}0.014 \\
(0.080)\end{array}$ & $\begin{array}{l}-0.009 \\
(0.058)\end{array}$ \\
\hline Population (log) & $\begin{array}{c}0.320 * * \\
(0.132)\end{array}$ & $\begin{array}{c}0.394^{* * *} \\
(0.140)\end{array}$ & $\begin{array}{c}0.242 \\
(0.192)\end{array}$ & $\begin{array}{l}0.203 \text { * } \\
(0.112)\end{array}$ \\
\hline FDI (log) & $\begin{array}{c}-0.470 \text { *** } \\
(0.121)\end{array}$ & $\begin{array}{c}-0.474^{* * *} \\
(0.129)\end{array}$ & $\begin{array}{c}-0.798^{* * *} \\
(0.230)\end{array}$ & $\begin{array}{c}-0.380^{* *} \\
(0.151)\end{array}$ \\
\hline Trade (log) & $\begin{array}{c}0.352 \\
(0.415)\end{array}$ & $\begin{array}{c}0.633 \\
(0.450)\end{array}$ & $\begin{array}{c}0.806 \\
(0.830)\end{array}$ & $\begin{array}{c}0.007 \\
(0.465)\end{array}$ \\
\hline Democracy & $\begin{array}{l}-0.036 \\
(0.290)\end{array}$ & $\begin{array}{c}0.018 \\
(0.289)\end{array}$ & $\begin{array}{c}0.455 \\
(0.545)\end{array}$ & $\begin{array}{l}-0.266 \\
(0.233)\end{array}$ \\
\hline Civil Violence & $\begin{array}{c}0.266^{* *} \\
(0.115)\end{array}$ & $\begin{array}{c}0.330^{* * *} \\
(0.122)\end{array}$ & & \\
\hline Constant & $\begin{array}{l}5.699 * \\
(2.995)\end{array}$ & $\begin{array}{c}3.757 \\
(2.980)\end{array}$ & $\begin{array}{c}7.347 \\
(6.360)\end{array}$ & $\begin{array}{c}5.023 \\
(4.332)\end{array}$ \\
\hline Region Fixed Effects & YES & YES & YES & YES \\
\hline Observations & 443 & 443 & 77 & 328 \\
\hline
\end{tabular}

Robust standard errors in parentheses. ${ }^{* * *} p<0.01,{ }^{* *} p<0.05,{ }^{*} p<0.1$.

\section{Appendix C. Fixed Effects No Selection Control}

Note: the social compliance model would not converge due to the small sample size. Furthermore, any country for which the value of child labor did not change over this period of time is dropped from the analysis due to non-variance. This model significantly reduces the sample size as a result of multiple countries being omitted. 


\begin{tabular}{|c|c|c|c|}
\hline \multirow[b]{2}{*}{ Probit } & \multicolumn{3}{|c|}{ Child Labor } \\
\hline & 1 & 2 & 3 \\
\hline Social Policies Met & $\begin{array}{c}0.894 \\
(0.558)\end{array}$ & & \\
\hline Revenue Policies Met & & $\begin{array}{c}0.424 \\
(0.277)\end{array}$ & \\
\hline Revenue Compliance & & & $\begin{array}{c}8.142^{* * *} \\
(2.678)\end{array}$ \\
\hline GDP (log) & $\begin{array}{l}-0.486 \\
(0.389)\end{array}$ & $\begin{array}{l}-0.484 \\
(0.614)\end{array}$ & $\begin{array}{c}3.368^{* *} \\
(1.509)\end{array}$ \\
\hline Population (log) & $\begin{array}{c}0.467 \\
(1.527)\end{array}$ & $\begin{array}{l}-0.093 \\
(2.343)\end{array}$ & $\begin{array}{l}-5.179 \\
(3.526)\end{array}$ \\
\hline FDI $(\log )$ & $\begin{array}{l}-0.846 \\
(0.546)\end{array}$ & $\begin{array}{c}-1.080 * * * \\
(0.374)\end{array}$ & $\begin{array}{l}-2.127 \\
(1.405)\end{array}$ \\
\hline Trade (log) & $\begin{array}{c}0.286 \\
(1.639)\end{array}$ & $\begin{array}{c}2.061 \\
(2.076)\end{array}$ & $\begin{array}{c}-11.194^{* * *} \\
(3.244)\end{array}$ \\
\hline Democracy & $\begin{array}{c}-4.330 * * * \\
(0.327)\end{array}$ & $\begin{array}{c}-4.147^{* * *} \\
(0.328)\end{array}$ & $\begin{array}{c}-8.471^{* * *} \\
(1.402)\end{array}$ \\
\hline Civil Violence & $\begin{array}{c}2.788^{* * *} \\
(0.774)\end{array}$ & $\begin{array}{c}3.644^{* * * *} \\
(1.390)\end{array}$ & \\
\hline Constant & $\begin{array}{c}21.264 \\
(20.006)\end{array}$ & $\begin{array}{c}26.537 \\
(28.584)\end{array}$ & $\begin{array}{c}99.457 * * \\
(42.569)\end{array}$ \\
\hline Observations & 103 & 103 & 51 \\
\hline
\end{tabular}

Appendix D. Two-Equation Conditional Mixed Process Estimator

\begin{tabular}{|c|c|c|c|c|}
\hline \multirow[b]{2}{*}{ Equation (2) } & \multicolumn{4}{|c|}{ Child Labor } \\
\hline & Model 1 & Model 2 & Model 3 & Model 4 \\
\hline IMF social policies met & $\begin{array}{c}0.804^{* * *} \\
(0.215)\end{array}$ & & & \\
\hline IMF revenue policies met & & $\begin{array}{c}0.295^{* * *} \\
(0.112)\end{array}$ & & \\
\hline IMF social compliance & & & $\begin{array}{c}1.826^{* * *} \\
(0.625)\end{array}$ & \\
\hline IMF revenue compliance & & & & $\begin{array}{c}0.582 \\
(0.842)\end{array}$ \\
\hline Lagged DV & $\begin{array}{c}1.471^{* * *} \\
(0.323)\end{array}$ & $\begin{array}{c}1.252 * * * \\
(0.334)\end{array}$ & $\begin{array}{c}2.125^{* * *} \\
(0.799)\end{array}$ & $\begin{array}{c}1.960 * * * \\
(0.465)\end{array}$ \\
\hline GDP per capita (log) & $\begin{array}{l}-0.072 \\
(0.048)\end{array}$ & $\begin{array}{c}-0.090 * \\
(0.047)\end{array}$ & $\begin{array}{l}-0.008 \\
(0.068)\end{array}$ & $\begin{array}{l}-0.011 \\
(0.055)\end{array}$ \\
\hline Population (log) & $\begin{array}{c}0.328^{* * *} \\
(0.126)\end{array}$ & $\begin{array}{c}0.393 * * * \\
(0.139)\end{array}$ & $\begin{array}{c}0.219 \\
(0.179)\end{array}$ & $\begin{array}{l}0.197^{*} \\
(0.105)\end{array}$ \\
\hline FDI $(\log )$ & $\begin{array}{c}-0.494^{* * *} \\
(0.114)\end{array}$ & $\begin{array}{c}-0.480^{* * *} \\
(0.124)\end{array}$ & $\begin{array}{c}-0.762^{* * *} \\
(0.216)\end{array}$ & $\begin{array}{c}-0.375^{* * *} \\
(0.123)\end{array}$ \\
\hline Trade (log) & $\begin{array}{c}0.389 \\
(0.391)\end{array}$ & $\begin{array}{c}0.639 \\
(0.443)\end{array}$ & $\begin{array}{c}0.604 \\
(0.742)\end{array}$ & $\begin{array}{l}-0.011 \\
(0.427)\end{array}$ \\
\hline Democracy & $\begin{array}{c}0.007 \\
(0.282)\end{array}$ & $\begin{array}{c}0.028 \\
(0.285)\end{array}$ & $\begin{array}{c}0.328 \\
(0.577)\end{array}$ & $\begin{array}{l}-0.274 \\
(0.244)\end{array}$ \\
\hline Civil Violence & $\begin{array}{c}0.279 * * \\
(0.118)\end{array}$ & $\begin{array}{c}0.333^{* * *} \\
(0.125)\end{array}$ & N.A. & N.A. \\
\hline Constant & $\begin{array}{l}5.566 * \\
(2.919)\end{array}$ & $\begin{array}{c}3.771 \\
(2.994)\end{array}$ & $\begin{array}{c}8.650 \\
(5.654)\end{array}$ & $\begin{array}{c}5.166 \\
(4.597)\end{array}$ \\
\hline Region Fixed Effects & YES & YES & YES & YES \\
\hline
\end{tabular}




\begin{tabular}{|c|c|c|c|c|}
\hline \multirow{2}{*}{$\begin{array}{c}\text { Equation (1) } \\
\text { UN Security Council }\end{array}$} & \multicolumn{4}{|c|}{ IMF Program Participation } \\
\hline & $\begin{array}{l}-0.115 \\
(0.201)\end{array}$ & $\begin{array}{l}-0.119 \\
(0.202)\end{array}$ & $\begin{array}{l}-0.121 \\
(0.203)\end{array}$ & $\begin{array}{l}-0.120 \\
(0.203)\end{array}$ \\
\hline OECD & $\begin{array}{l}-0.446^{* *} \\
(0.227)\end{array}$ & $\begin{array}{l}-0.448^{* *} \\
(0.228)\end{array}$ & $\begin{array}{l}-0.449^{* *} \\
(0.228)\end{array}$ & $\begin{array}{l}-0.449^{* *} \\
(0.228)\end{array}$ \\
\hline GDP per capita (log) & $\begin{array}{c}0.023 \\
(0.035)\end{array}$ & $\begin{array}{c}0.023 \\
(0.035)\end{array}$ & $\begin{array}{c}0.023 \\
(0.035)\end{array}$ & $\begin{array}{c}0.023 \\
(0.035)\end{array}$ \\
\hline Population (log) & $\begin{array}{c}0.211^{* * *} \\
(0.073)\end{array}$ & $\begin{array}{c}0.211^{* * *} \\
(0.073)\end{array}$ & $\begin{array}{l}0.211^{* * *} \\
(0.073)\end{array}$ & $\begin{array}{l}0.211^{* * *} \\
(0.073)\end{array}$ \\
\hline FDI (log) & $\begin{array}{c}-0.136^{* * *} \\
(0.041)\end{array}$ & $\begin{array}{l}-0.135^{* * *} \\
(0.041)\end{array}$ & $\begin{aligned}-0.135^{* * *} \\
(0.041)\end{aligned}$ & $\begin{aligned}- & 0.136^{* * *} \\
& (0.041)\end{aligned}$ \\
\hline Trade (log) & $\begin{array}{c}0.148 \\
(0.125)\end{array}$ & $\begin{array}{c}0.148 \\
(0.125)\end{array}$ & $\begin{array}{c}0.148 \\
(0.125)\end{array}$ & $\begin{array}{c}0.148 \\
(0.125)\end{array}$ \\
\hline $\begin{array}{l}\text { Inflation, consumer prices } \\
\text { (annual\%) }\end{array}$ & -0.001 & -0.001 & -0.001 & -0.001 \\
\hline & $(0.007)$ & $(0.007)$ & $(0.007)$ & $(0.007)$ \\
\hline Total reserves & $\begin{array}{l}-0.000 * * * \\
(0.000)\end{array}$ & $\begin{array}{l}-0.000 * * * \\
(0.000)\end{array}$ & $\begin{array}{l}-0.000 * * * \\
(0.000)\end{array}$ & $\begin{aligned}- & 0.000 * * * \\
& (0.000)\end{aligned}$ \\
\hline GDP growth (annual \%) & $\begin{array}{c}0.000 \\
(0.009)\end{array}$ & $\begin{array}{c}0.000 \\
(0.009)\end{array}$ & $\begin{array}{c}0.000 \\
(0.009)\end{array}$ & $\begin{array}{c}0.000 \\
(0.009)\end{array}$ \\
\hline Civil Violence & $\begin{array}{c}0.586^{* * *} \\
(0.175)\end{array}$ & $\begin{array}{l}0.586^{* * *} \\
(0.175)\end{array}$ & $\begin{array}{l}0.586^{* * *} \\
(0.175)\end{array}$ & $\begin{array}{c}0.586^{* * *} \\
(0.175)\end{array}$ \\
\hline Democracy & $\begin{array}{c}0.175 \\
(0.161)\end{array}$ & $\begin{array}{c}0.175 \\
(0.161)\end{array}$ & $\begin{array}{c}0.174 \\
(0.161)\end{array}$ & $\begin{array}{c}0.175 \\
(0.161)\end{array}$ \\
\hline Number of IMF borrowers & $\begin{array}{l}0.016^{* * *} \\
(0.004)\end{array}$ & $\begin{array}{c}0.016^{* * *} \\
(0.004)\end{array}$ & $\begin{array}{l}0.016^{* * *} \\
(0.004)\end{array}$ & $\begin{array}{l}0.016^{* * *} \\
(0.004)\end{array}$ \\
\hline Year & $\begin{array}{c}0.013 \\
(0.019)\end{array}$ & $\begin{array}{c}0.014 \\
(0.019)\end{array}$ & $\begin{array}{c}0.015 \\
(0.019)\end{array}$ & $\begin{array}{c}0.015 \\
(0.019)\end{array}$ \\
\hline Crisis & $\begin{array}{c}0.015 \\
(0.153)\end{array}$ & $\begin{array}{c}0.008 \\
(0.153)\end{array}$ & $\begin{array}{c}0.005 \\
(0.153)\end{array}$ & $\begin{array}{c}0.004 \\
(0.154)\end{array}$ \\
\hline Constant & $\begin{array}{l}-29.889 \\
(38.330)\end{array}$ & $\begin{array}{l}-31.561 \\
(38.413)\end{array}$ & $\begin{array}{l}-32.291 \\
(38.596)\end{array}$ & $\begin{array}{l}-32.508 \\
(38.539)\end{array}$ \\
\hline Rho & $\begin{array}{c}0.150 \\
(0.127)\end{array}$ & $\begin{array}{c}0.053 \\
(0.133)\end{array}$ & $\begin{array}{l}-0.162 \\
(0.278)\end{array}$ & $\begin{array}{l}-0.030 \\
(0.232)\end{array}$ \\
\hline Observations & 1802 & 1802 & 1796 & 1802 \\
\hline
\end{tabular}

Robust clustered standard errors in parentheses. Region fixed effects included in outcome model. $* * * p<0.01,{ }^{* *} p<0.05,{ }^{*} p<0.1$. 
Appendix E. Bivariate Probit Model

\begin{tabular}{|c|c|c|c|c|}
\hline \multirow[b]{2}{*}{ Equation (2) } & \multicolumn{4}{|c|}{ Child Labor } \\
\hline & Model 1 & Model 2 & Model 3 & Model 4 \\
\hline Number of Social Policies Met & $\begin{array}{c}0.757^{* * *} \\
(0.224)\end{array}$ & & & \\
\hline Number of Revenue Policies Met & & $\begin{array}{c}0.290 * * * \\
(0.113)\end{array}$ & & \\
\hline Percent of Social Policies Met & & & $\begin{array}{l}1.206^{*} \\
(0.688)\end{array}$ & \\
\hline Percent of Compliance Policies Met & & & & $\begin{array}{c}0.540 \\
(0.833)\end{array}$ \\
\hline Lagged DV & $\begin{array}{c}1.473^{* * *} \\
(0.333)\end{array}$ & $\begin{array}{c}1.248^{* * *} \\
(0.344)\end{array}$ & $\begin{array}{c}1.969 * * * \\
(0.634)\end{array}$ & $\begin{array}{c}1.948^{* * *} \\
(0.479)\end{array}$ \\
\hline GDP per capita (log) & $\begin{array}{l}-0.067 \\
(0.046)\end{array}$ & $\begin{array}{c}-0.085^{*} \\
(0.048)\end{array}$ & $\begin{array}{l}-0.091 \\
(0.092)\end{array}$ & $\begin{array}{l}-0.017 \\
(0.047)\end{array}$ \\
\hline Population (log) & $\begin{array}{c}0.339 \text { ** } \\
(0.134)\end{array}$ & $\begin{array}{c}0.414^{* * *} \\
(0.142)\end{array}$ & $\begin{array}{c}0.465 \\
(0.558)\end{array}$ & $\begin{array}{l}0.212 * \\
(0.110)\end{array}$ \\
\hline FDI (log) & $\begin{array}{c}-0.460 * * * \\
(0.116)\end{array}$ & $\begin{array}{c}-0.468^{* * *} \\
(0.130)\end{array}$ & $\begin{array}{c}-0.950 * \\
(0.573)\end{array}$ & $\begin{array}{c}-0.381^{* * *} \\
(0.146)\end{array}$ \\
\hline Trade (log) & $\begin{array}{c}0.511 \\
(0.374)\end{array}$ & $\begin{array}{l}0.754 \text { * } \\
(0.439)\end{array}$ & $\begin{array}{c}0.874 \\
(1.332)\end{array}$ & $\begin{array}{c}0.040 \\
(0.405)\end{array}$ \\
\hline Democracy & $\begin{array}{c}0.002 \\
(0.270)\end{array}$ & $\begin{array}{c}0.049 \\
(0.273)\end{array}$ & $\begin{array}{l}-0.212 \\
(0.779)\end{array}$ & $\begin{array}{l}-0.276 \\
(0.232)\end{array}$ \\
\hline Time under Minimum Age Treaty & $\begin{array}{l}-0.012 \\
(0.011)\end{array}$ & $\begin{array}{l}-0.011 \\
(0.011)\end{array}$ & $\begin{array}{l}-0.069 \\
(0.064)\end{array}$ & $\begin{array}{l}-0.010 \\
(0.010)\end{array}$ \\
\hline Civil Violence & $\begin{array}{c}0.222 * * \\
(0.108)\end{array}$ & $\begin{array}{c}0.309 * * \\
(0.121)\end{array}$ & $\begin{array}{c}0.046 \\
(0.162)\end{array}$ & $\begin{array}{c}2.870 * * * \\
(0.395)\end{array}$ \\
\hline Region Fixed Effects & YES & YES & YES & YES \\
\hline Constant & $\begin{array}{l}4.273 * \\
(2.386)\end{array}$ & $\begin{array}{c}2.728 \\
(2.623)\end{array}$ & $\begin{array}{c}10.614^{*} \\
(6.010)\end{array}$ & $\begin{array}{c}5.095 \\
(4.060)\end{array}$ \\
\hline Equation (1) & & IMF Progra & articipation & \\
\hline UN Security Council & $\begin{array}{c}0.543 \\
(0.380)\end{array}$ & $\begin{array}{c}0.530 \\
(0.381)\end{array}$ & $\begin{array}{c}0.184 \\
(0.488)\end{array}$ & $\begin{array}{c}0.567 \\
(0.486)\end{array}$ \\
\hline OECD & $\begin{array}{l}0.512 * \\
(0.269)\end{array}$ & $\begin{array}{l}0.517^{*} \\
(0.273)\end{array}$ & $\begin{array}{c}-1.026^{* * *} \\
(0.312)\end{array}$ & $\begin{array}{c}0.206 \\
(0.462)\end{array}$ \\
\hline GDP per capita (log) & $\begin{array}{c}0.014 \\
(0.038)\end{array}$ & $\begin{array}{c}0.014 \\
(0.038)\end{array}$ & $\begin{array}{l}-0.038 \\
(0.066)\end{array}$ & $\begin{array}{c}0.045 \\
(0.054)\end{array}$ \\
\hline Population (log) & $\begin{array}{l}-0.016 \\
(0.096)\end{array}$ & $\begin{array}{l}-0.015 \\
(0.096)\end{array}$ & $\begin{array}{c}0.029 \\
(0.246)\end{array}$ & $\begin{array}{l}-0.024 \\
(0.113)\end{array}$ \\
\hline FDI (log) & $\begin{array}{c}-0.113^{* *} \\
(0.049)\end{array}$ & $\begin{array}{c}-0.113^{* *} \\
(0.049)\end{array}$ & $\begin{array}{l}-0.130 \\
(0.154)\end{array}$ & $\begin{array}{l}-0.064 \\
(0.059)\end{array}$ \\
\hline Trade (log) & $\begin{array}{c}0.062 \\
(0.249)\end{array}$ & $\begin{array}{c}0.060 \\
(0.249)\end{array}$ & $\begin{array}{l}-0.142 \\
(0.502)\end{array}$ & $\begin{array}{c}0.066 \\
(0.316)\end{array}$ \\
\hline Inflation & $\begin{array}{c}0.018^{* *} \\
(0.008)\end{array}$ & $\begin{array}{l}0.018^{* *} \\
(0.008)\end{array}$ & $\begin{array}{c}0.008 \\
(0.016)\end{array}$ & $\begin{array}{c}0.019 * * \\
(0.009)\end{array}$ \\
\hline Total reserves & $\begin{array}{c}0.000 \\
(0.000)\end{array}$ & $\begin{array}{c}0.000 \\
(0.000)\end{array}$ & $\begin{array}{l}-0.000 \\
(0.000)\end{array}$ & $\begin{array}{l}-0.000 \\
(0.000)\end{array}$ \\
\hline GDP growth (annual \%) & $\begin{array}{l}-0.003 \\
(0.016)\end{array}$ & $\begin{array}{l}-0.004 \\
(0.015)\end{array}$ & $\begin{array}{c}-0.135^{* *} \\
(0.056)\end{array}$ & $\begin{array}{c}0.002 \\
(0.018)\end{array}$ \\
\hline Civil Violence & $\begin{array}{c}0.211^{* * *} \\
(0.079)\end{array}$ & $\begin{array}{c}0.209 * * * \\
(0.078)\end{array}$ & $\begin{array}{c}1.896^{* * *} \\
(0.156)\end{array}$ & $\begin{array}{l}-0.058 \\
(0.103)\end{array}$ \\
\hline Democracy & $\begin{array}{l}-0.143 \\
(0.169)\end{array}$ & $\begin{array}{l}-0.144 \\
(0.169)\end{array}$ & $\begin{array}{l}-0.202 \\
(0.389)\end{array}$ & $\begin{array}{l}-0.041 \\
(0.190)\end{array}$ \\
\hline Number of IMF Borrowers & $\begin{array}{l}-0.013 \\
(0.010)\end{array}$ & $\begin{array}{l}-0.014 \\
(0.010)\end{array}$ & $\begin{array}{l}-0.020 \\
(0.016)\end{array}$ & $\begin{array}{l}-0.016 \\
(0.012)\end{array}$ \\
\hline Year & $\begin{array}{l}-0.009 \\
(0.040)\end{array}$ & $\begin{array}{l}-0.007 \\
(0.040)\end{array}$ & $\begin{array}{c}0.090 \\
(0.089)\end{array}$ & $\begin{array}{l}-0.061 \\
(0.044)\end{array}$ \\
\hline Crisis & $\begin{array}{c}0.191 \\
(0.368)\end{array}$ & $\begin{array}{c}0.177 \\
(0.367)\end{array}$ & $\begin{array}{l}-0.427 \\
(0.679)\end{array}$ & $\begin{array}{c}0.567 \\
(0.397)\end{array}$ \\
\hline Rho & $\begin{array}{c}0.100 \\
(0.176)\end{array}$ & $\begin{array}{l}-0.029 \\
(0.171)\end{array}$ & $\begin{array}{c}-8.295 \\
(44.858)\end{array}$ & $\begin{array}{c}0.047 \\
(0.243)\end{array}$ \\
\hline Constant & $\begin{array}{c}21.407 \\
(80.423)\end{array}$ & $\begin{array}{c}17.712 \\
(80.416)\end{array}$ & $\begin{array}{l}-174.044 \\
(176.035)\end{array}$ & $\begin{array}{l}123.797 \\
(87.755)\end{array}$ \\
\hline Observations & 443 & 443 & 115 & 337 \\
\hline
\end{tabular}

Robust standard errors in parentheses. ${ }^{* *} p<0.01,{ }^{* *} p<0.05,{ }^{*} p<0.1$. 
Appendix F. No Lagged DV No Selection

\begin{tabular}{lcccc}
\hline & \multicolumn{4}{c}{ Child Labor } \\
\cline { 2 - 5 } Probit & Model 1 & Model 2 & Model 3 & Model 4 \\
\hline Number Social Policies Met & $0.437^{*}$ & & \\
Number Revenue Policies Met & $(0.251)$ & $0.354^{* * *}$ & & \\
Percent Social Policies Met & & $(0.129)$ & $0.826^{*}$ & \\
& & & $(0.452)$ & \\
Percent Revenue Policies Met & & & 0.404 \\
& & & & $(0.672)$ \\
Log GDP & -0.059 & -0.070 & 0.003 & -0.047 \\
& $(0.052)$ & $(0.051)$ & $(0.092)$ & $(0.080)$ \\
Log Population & $0.390^{* * *}$ & $0.477^{* * *}$ & 0.281 & $0.228^{*}$ \\
& $(0.146)$ & $(0.149)$ & $(0.227)$ & $(0.137)$ \\
Log FDI & $-0.601 * * *$ & $-0.604 * * *$ & $-0.963 * * *$ & $-0.547^{* * *}$ \\
& $(0.134)$ & $(0.137)$ & $(0.249)$ & $(0.181)$ \\
Log Trade (\% GDP) & 0.467 & 0.827 & 1.152 & 0.092 \\
& $(0.497)$ & $(0.519)$ & $(1.183)$ & $(0.572)$ \\
Democracy (Binary) & -0.051 & 0.084 & $0.867^{*}$ & -0.029 \\
& $(0.365)$ & $(0.336)$ & $(0.516)$ & $(0.353)$ \\
Civil Violence & $0.261^{* *}$ & $0.324^{* *}$ & OMITTED & OMITTED \\
Constant & $(0.129)$ & $(0.132)$ & & \\
& $7.430^{* *}$ & 4.632 & 10.690 & $10.341^{* *}$ \\
Region Fixed Effects & $(3.231)$ & $(2.951)$ & $(9.349)$ & $(5.204)$ \\
Observations & YES & YES & YES & YES \\
\hline & 446 & 446 & 78 & 331 \\
\hline
\end{tabular}

Robust clustered standard errors in parentheses. Region fixed effects included in all models. ${ }^{* * *} p<0.01,{ }^{* *} p<0.05, * p<0.1$.

\section{Appendix G. One- and Two-Year Lags}

\begin{tabular}{lcc}
\hline & \multicolumn{2}{c}{ Child Labor } \\
\cline { 2 - 3 } Probit & $\mathbf{1}$ & $\mathbf{2}$ \\
\hline Social Policies Met (T-1) & $0.739^{* * *}$ & \\
& $(0.211)$ & \\
Social Policies Met (T-2) & 0.198 & $0.354^{* *}$ \\
Revenue Policies Met (T-1) & $(0.253)$ & $(0.164)$ \\
& & $0.270^{* *}$ \\
Revenue Policies Met (T-2) & & $(0.109)$ \\
& & $1.277^{* * *}$ \\
Lagged DV & $1.659^{* * *}$ & $(0.322)$ \\
& $(0.356)$ & $-0.141^{* *}$ \\
Log GDP & $-0.124^{*}$ & $(0.067)$ \\
& $(0.072)$ & $0.680^{* * *}$ \\
Log Population & $0.476^{* * *}$ & $(0.218)$ \\
& $(0.151)$ & $-0.779 * *$ \\
Log FDI & $-0.683^{* * *}$ & $(0.243)$ \\
Log Trade (\% GDP) & $(0.191)$ & $1.300^{* *}$ \\
Democracy (Binary) & 0.535 & $(0.617)$ \\
Civil Violence & $(0.433)$ & 0.165 \\
& 0.043 & $(0.376)$ \\
IMF Selection & $(0.334)$ & $1.188^{* * *}$ \\
& $0.912^{* * *}$ & $(0.381)$ \\
Constant & $(0.329)$ & $-4.862^{* *}$ \\
Regional Fixed Effects & $-3.966^{* *}$ & $(2.018)$ \\
Observations & $(1.930)$ & 5.236 \\
\hline & $9.160^{* *}$ & $(3.545)$ \\
Robust & $(4.006)$ & 326 \\
\hline
\end{tabular}

Robust standard errors in parentheses. ${ }^{* * *} p<0.01,{ }^{* *} p<0.05,{ }^{*} p<0.1$. 


\section{Appendix H. A Note on WorkR2}

The WorkR2 data measures seven worker rights in law and practice. The data uses the US State Department Reports on Human Rights to code government respect for labor rights for every country of the world. For child labor, the data examines whether individuals under 14 years of age are prohibited from employment in the private or public sector. Countries should restrict child employment in hazardous occupations, during normal school hours, or in the case that children are unhealthy. Children should not be subject to sexual exploitation or serve as soldiers in conflict of any kind. If children's rights are violated then there should be legal remedy and/or government action to redress these violations. Work for family members, in petty commodity production, or begging is not coded as a violation of child labor. The data are scored on a 0 (widespread violations) 1 (some violations) 2 (no violations) scale. For the sake of this paper, we are interested in whether child labor exists, and have opted to dichotomize this measure.

\section{Appendix I. A Note on SCIP}

The SCIP data was produced by Mark (2018) and comes in three datasets, each measuring a different unit of analysis. We use the SCIP-Y dataset, which is measured at the country-year level, because all of our covariates are country-year measures. The dataset codes each condition attached to an IMF loan into one of 18 different policy categories using the MONA Combined dataset. The dataset removes duplicate policies, policies with spelling errors, and policies which have been met in a previous review period. For each policy, the dataset codes whether the condition was met, not met, partially met, modified, or cancelled. We opt for social policies and revenue policies because we are following the advances in the IMF literature, which has moved beyond IMF conditionality as a whole, and has begun examining the effects of specific policies on outcomes of interest (see for example Vreeland 2006; Rickard and Caraway 2019). To our knowledge, this is the only dataset that has compliance data for policy-specific conditionality.

\section{Notes}

1 See (Basu 1999, p. 1111). Even ratification of an ILO convention only allows for very limited monitoring, with progress reported in three ways: (1) governments submit reports on their own compliance, (2) workers' organizations report to the ILO on government compliance, and (3) other member countries report to the ILO on the government's compliance. When noncompliance is reported, the ILO has the power to open a dialogue with the government about its noncompliance in order to provide assistance and support. but without formal power to punish governments who do not comply (Brown 2001, p. 108). Instead, the ILO must rely on other member governments to impose sanctions or cut trade and aid to countries who do not comply-these are the most common forms of international pressure to improve child labor conditions. Hypothetically, the World Trade Organization (WTO) has much more power to enforce child labor protections through the threat of sanctions and embargoes, but whether or not the WTO should adopt these kinds of labor standards is the topic of much controversy (Basu 1999, p. 1111). Some argue that the economic advantages from child labor are unfair and should be punished, while others argue that sanctions would only make the situation worse for children as countries lose their comparative advantage on the international market and children lose their jobs (Bhagwati 1995; Collingsworth et al. 1994). Today, the WTO remains uninvolved with labor standards altogether as the issue remains contentious, "and the question of international enforcement is a minefield (World Trade Organization 2019)."

2 For example, (Admassie 2002; Edmonds 2004, 2005; Kielland and Tovo 2006; Labenne 1997; Rosenzweig 1981; Schultz 1960).

3 (Easterly 2000, 2003). Additionally, Nooruddin and Simmons (2006) find that impoverished people in democracies under reforms bear the burden of cuts to education and healthcare spending; while not all countries under reforms are democracies, $61 \%$ of country-years in our sample are coded as democracies based on the Boix-Miller-Rosato dichotomous coding for democracy.

4 For example, (Canagarajah and Coulombe 1997; Cardoso and Dorte 2007; Cockburn 2001; Edmonds 2004; Patrinos and Psacharopoulos 1997; Ray 2000).

5 (Rowden 2013; Stuckler et al. 2008). The examples above in brackets are all taken from the SCIP dataset discussed in the research design section. 
6 For example, (Cigno and Rosati 2002; De Tray 1983; Patrinos and Psacharopoulos 1997).

7 Our sample consists of countries under IMF lending and excludes any country-year in which a country is not under IMF lending. This sampling approach is similar to (Rickard and Caraway 2019).

8 Mosley and Uno 2007 identify trade and fdi as important determinants of labor rights. Blanton, Blanton, and Peksen in their work on IMF and World Bank Programs also add GDP per capita, regime type population, civil conflict, and a lagged dependent variable as important determinants of both IMF participation and labor rights outcomes. These controls are also in line with (Abouharb and Cingranelli 2007, 2009; Mark 2018).

9 Descriptive statistics are available in the Appendices A-I.

10 See (Ortiz and Béjar 2013; Stubbs et al. 2020).

11 See Appendix B for results without the inverse-mills ratio included.

12 Control variables in our selection equation are similar to those from our outcome equation. For our purposes the determinants of IMF participation are similar to IMF compliance insofar as both affect child labor. We include OECD membership as a proxy for whether a country is developed as (Mark 2018) notes that developed countries rarely take out IMF loans. We also include inflation, total reserves, and GDP growth as measures of economic distress. Our control variables are largely consistent with (Abouharb and Cingranelli 2007, 2009) as well as (Blanton et al. 2015; Mark 2018).

13 See, (Dreher et al. 2015).

14 See, for example, (Mosley and Uno 2007).

15 We find that the results are unchanged with no lags. When lagging the variables 2 years, the results are largely unchanged with the exception of social policies, which is indistinguishable from zero. For more than 2 years, the sample size decreases to the point of nonconvergence.

16 For example, (Abouharb and Cingranelli 2007; Martin and Brady 2007; Blanton et al. 2015).

17 For example, (Vreeland 2002).

\section{References}

Abouharb, M. Rodwan, and David Cingranelli. 2007. Human Rights and Structural Adjustment. New York: Cambridge University Press. Abouharb, M. Rodwan, and David L. Cingranelli. 2009. IMF Programs and Human Rights, 1981-2003. Review of International Organizations 4: 47. [CrossRef]

Admassie, Assefa. 2002. Explaining the High Incidence of Child Labour in Sub-Saharan Africa. African Development Review 14: $251-75$. [CrossRef]

Ahmed, Iftikhar. 1999. Getting Rid of Child Labor. Economic and Political Weekly 34: 1815-22.

Ahmed, Saifuddin, Qingfeng Li, Li Liu, and Amy O. Tsui. 2012. Maternal Deaths Averted by Contraceptive Use: An Analysis of 172 Countries. Lancet 380: 111-25. [CrossRef]

Barro, Robert, and Jong-Wha Lee. 2005. IMF "Programs: Who is Chosen and What are the Effects?". Journal of Monetary Economics 57: 1245-69. [CrossRef]

Bas, Muhammet A., and Randall W. Stone. 2014. Adverse Selection and Growth under IMF Programs. Review of International Organizations 9: 1-28. [CrossRef]

Bass, Loretta E. 2004. Child Labor in Sub-Saharan Africa. Boulder: Lynne Rienner Publishers, Inc.

Basu, Kaushik. 1999. International Labor Standards and Child Labor. Challenge 42: 80-93. [CrossRef]

Basu, Kaushik, and Pham Voang Van. 1998. The Economics of Child Labor. American Economic Review, 412-27. [CrossRef]

Bhagwati, Jagdish. 1995. Trade Liberalization and 'Fair Trade' Demands: Addressing the Environment and Labor Standards Issues. World Economy 18: 745-59. [CrossRef]

Blanton, Robert G., Shannon Lindsey Blanton, and Dursun Peksen. 2015. The Impact of IMF and World Bank Programs on Labor Rights. Political Research Quarterly 68: 324-36. [CrossRef]

Blanton, Robert G., Bryan Early, and Dursun Peksen. 2018. Out of the Shadows or Into the Dark? Economic Openness, IMF Programs, and the Growth of Shadow Economies. Review of International Organizations 28: 309-33. [CrossRef]

Boggan, Steve. 2001. 'We Blew It': Nike Admits to Mistakes over Child Labor. In The Independent. London: Independent Digital News \& Media Ltd.

Boix, Carles, Michael K. Miller, and Sebastian Rosato. 2013. A Complete Data Set of Political Regimes, 1800-2007. Comparative Political Studies 46: 1523-54. [CrossRef]

Boughton, James. 2001. Silent Revolution: The International Monetary Fund, 1979-1989. Washington, DC: International Monetary Fund.

Brown, Drusilla K. 2001. Labor Standards: Where Do They Belong on the International Trade Agenda? Journal of Economic Perspectives 15: 89-112. [CrossRef]

Burgoon, Brian. 2001. Globalization and Welfare Compensation: Disentangling the Ties That Bind. International Organization 55: 509-51. [CrossRef]

Camdessus, Michel. 1996. Promoting Freer Trade: The IMF's Perspective—Remarks by Michel Camdessus. IMF. December 9. Available online: https:/ /www.imf.org/en/News/Articles/2015/09/28/04/53/spmds9621 (accessed on 1 April 2021). 
Canagarajah, Sudharshan, and Harold Coulombe. 1997. Child Labor and Schooling in Ghana (No. 1844). Washington, DC: World Bank.

Cardoso, Ana Rute, and Verner Dorte. 2007. School Drop-Out and Push-Out Factors in Brazil: The Role of Early Parenthood, Child Labor, and Poverty. World Bank Policy Research Working Paper Series; Washington, DC: World Bank.

Chernichovsky, Dov. 1985. Socioeconomic and Demographic Aspects of School Enrollment and Attendance in Rural Botswana. Economic Development and Cultural Change 32: 319-32. [CrossRef]

Cigno, Alessandro, and Furio Camillo Rosati. 2002. Child Labour Education and Nutrition in Rural India. Pacific Economic Review 7: 1-19. [CrossRef]

Cingranelli, David, and Brendan Skip Mark. 2021. Coding Guide: The National Worker Protections (WorkR2) Dataset. Manual Version Eight, April 19.

Clements, Benedict, Sanjeev Gupta, and Masahiro Nozaki. 2013. What Happens to Social Spending in IMF-Supported Programmes? Applied Economics 45: 4022-33. [CrossRef]

Cockburn, John. 2001. Child Labour Versus Education: Poverty Constraints or Income Opportunities? Oxford: Center for the Study of African Economies, Oxford University.

Collingsworth, Terry, William J. Goold, and Pharis J. Harvey. 1994. Time for a New Global Deal. Foreign Affairs 73: 8-13. [CrossRef]

Dammert, Ana C. 2008. Child Labor and Schooling Response to Changes in Coca Production in Rural Peru. Journal of Development Economics 86: 164-80. [CrossRef]

Darroch, Jacqueline E., Gilda Sedgh, and Haley Ball. 2011. Contraceptive Technologies: Responding to Women's Needs. New York: Guttmacher Institute.

De Tray, Dennis. 1983. Children's Work Activities in Malaysia. Population and Development Review 9: 437-55. [CrossRef]

Detraz, Nicole, and Dursun Peksen. 2016. The Effect of IMF Programs on Women's Economic and Political Rights. International Interactions 42: 81-105. [CrossRef]

Dreher, Axel. 2006. IMF and Economic Growth: The Effects of Programs, Loans, and Compliance with Conditionality. World Development 34: 769-88. [CrossRef]

Dreher, Axel, and Martin Gassebner. 2012. Do IMF and World Bank Programs Induce Government Crises? An Empirical Analysis. International Organization 66: 329-58.

Dreher, Axel, Jan-Egbert Sturm, and James Raymond Vreeland. 2015. Politics and IMF Conditionality. Journal of Conflict Resolution 59: 120-48. [CrossRef]

Easterly, William. 2000. The Effect of IMF and World Bank Programs on Poverty. Available online: https://ssrn.com/abstract=256883 (accessed on 31 August 2020).

Easterly, William. 2003. IMF and World Bank Structural Adjustment Programs and Poverty. In Managing Currency Crises in Emerging Markets. Edited by Michael P. Dooley and Jeffrey A. Frankel. Chicago: University of Chicago Press.

Edmonds, Eric. 2004. Does Illiquidity Alter Child Labor and Schooling Decisions? Evidence from Household Responses to Anticipated Cash Transfers in South Africa. NBER Working Paper No. 10265. Cambridge: National Bureau of Economic Research.

Edmonds, Eric. 2005. Does Child Labor Decline with Improving Economic Status? Journal of Human Resources 40: 77-99. [CrossRef]

Edmonds, Eric V. 2007. Understanding Sibling Differences in Child Labor. Journal of Population Economics 19: 795-821. [CrossRef]

Edmonds, Eric V., and Norbert Schady. 2012. Poverty Alleviation and Child Labor. American Economic Journal: Economic Policy 4: 100-24. [CrossRef]

Emerson, Patrick M., and André Portela Souza. 2008. Birth Order, Child Labor, and School Attendance in Brazil. World Development 36: 1647-64. [CrossRef]

Frankel, Jeffrey A., and David Romer. 1999. Does Trade Cause Growth? American Economic Review 89: 379-99. [CrossRef]

Garuda, Gopal. 2000. The Distributional Effects of IMF Programs: A Cross-country Analysis. World Development 28: 1031-51. [CrossRef]

Gericke, Alena, and Tiffani Crippin. 2017. When More Is More: The Problem of Sample Size in Maximum Likelihood Estimation. Madison: Annual Meeting for the Society for Political Methodology.

Grabel, Ilene. 2011. Not Your Grandfather's IMF: Global Crisis, 'Productive Incoherence' and Developmental Policy Space. Cambridge Journal of Economics 35: 805-30. [CrossRef]

Guarcello, Lorenzo, Scott Lyon, and Furio Camillo Rosati. 2008. Child Labor and Education for All: An Issue Paper. Journal of the History of Childhood and Youth 1: 254-66. [CrossRef]

Hafner-Burton, Emilie M., and Kiyoteru Tsutsui. 2005. Human Rights in a Globalizing World: The Paradox of Empty Promises. American Journal of Sociology 110: 1373-411. [CrossRef]

Hays, Jude C., Sean D. Ehrlich, and Clint Peinhardt. 2005. Government Spending and Public Support for Trade in the OECD: An Empirical Test of the Embedded Liberalism Thesis. International Organization 59: 473-94. [CrossRef]

Hellman, Joel S. 1998. Winners take all: The politics of partial reform in postcommunist transitions. World Politics 50: 203-34. [CrossRef]

IMF (International Monetary Fund). 2020. Monitoring of Fund Arrangements: MONA Database. Washington, DC: International Monetary Fund.

International Labor Organization. 2017. Global Estimates of Child Labour: Results and Trends, 2012-2016. Geneva: International Labour Organization.

Jensen, Nathan M. 2004. Crisis, Conditions, and Capital: The Effect of International Monetary Fund Agreements on Foreign Direct Investment Flows. Journal of Conflict Resolution 48: 194-210. [CrossRef]

Jorgie, Drazen. 2019. In Rare Move, Pakistan Military Agrees to Budget Cut Amid Economic Woes, PM Says. Reuters, June 5. 
Kentikelenis, Alexander, Lawrence King, Martin McKee, and David Stuckler. 2015. The International Monetary Fund and the Ebola Outbreak. The Lancet Global Health 3: e69-70. [CrossRef]

Kentikelenis, Alexander E., Thomas H. Stubbs, and Lawrence P. King. 2016. IMF Conditionality and Development Policy Space, 1985-2014. Review of International Political Economy 23: 543-82. [CrossRef]

Kielland, Anne, and Maurizia Tovo. 2006. Children at Work: Child Labor Practices in Africa. Boulder: Lynne Rienner Publishers, Inc.

Labenne, Sophie. 1997. The Determinants of Child Labor in India. Namur: Universite de Namur Centre of Research in the Economics of Development, Unpublished manuscript.

Levison, Deborah. 1991. Children's Labor Force Activity and Schooling in Brazil. Ph.D. Thesis, University of Michigan, Ann Arbor, AZ, USA.

Mark, Brendan Skip. 2018. Compliance with IMF Austerity: Labor Rights, Protest, and Repression. Ph.D. Thesis, Binghamton University, State University of New York, Binghamton, NY, USA.

Marphatia, Akanksha A. 2010. The Adverse Effects of International Monetary Fund Programs on the Health and Education Workforce. International Journal of Health Services 40: 165-78. [CrossRef]

Martin, Nathan D., and David Brady. 2007. Workers of the Less Developed World Unite? A Multilevel Analysis of Unionization in Less Developed Countries. American Sociological Review 72: 562-84. [CrossRef]

Morduch, Jonathan. 2000. Sibling Rivalry in Africa. American Economic Review 90: 405-9. [CrossRef]

Mosley, Layna. 2000. Room to Move: International Financial Markets and National Welfare States. International Organization 54: 737-73. [CrossRef]

Mosley, Layna, and Saika Uno. 2007. Racing to the bottom or climbing to the top? Economic globalization and collective labor rights. Comparative Political Studies 40: 923-48.

Neumayer, Eric. 2005. Do International Human Rights Treaties Improve Respect for Human Rights? Journal of Conflict Resolution 49: 925-53. [CrossRef]

Nolan, Aoife. 2011. Children's Socio-economic Rights, Democracy and the Courts. New York: Bloomsbury Publishing.

Nooruddin, Irfan, and Joel W. Simmons. 2006. The Politics of Hard Choices: IMF Programs and Government Spending. International Organization 60: 1001-33. [CrossRef]

Nooruddin, Irfan, and James Raymond Vreeland. 2010. The Effect of IMF Programs on Public Wages and Salaries. In Global Governance, Poverty and Inequality. Edited by Rorden Wilkinson and Jennifer Cla. New York: Taylor \& Francis Group, pp. 90-111.

Oberdabernig, Doris A. 2013. Revisiting the Effects of IMF Programs on Poverty and Inequality. World Development 46: 113-42. [CrossRef]

Ortiz, David G., and Sergio Béjar. 2013. Participation in IMF-Sponsored Economic Programs and Contentious Collective Action in Latin America, 1980-2007. Conflict Management and Peace Science 30: 492-515. [CrossRef]

Papi, Luca, Andrea F. Presbitero, and Alberto Zazzaro. 2015. IMF Lending and Banking Crises. IMF Economic Review 63: 644-91. [CrossRef]

Patrinos, Harry Anthony, and George Psacharopoulos. 1997. Family Size, Schooling and Child Labor in Peru: An Empirical Analysis. Journal of Population Economics 10: 387-405. [CrossRef]

Pion-Berlin, David. 1983. Political Repression and Economic Doctrines: The Case of Argentina. Comparative Political Studies 16: 37-66. [CrossRef]

Przeworski, Adam, and James Vreeland. 2000. The Effect of IMF Programs on Economic Growth. Journal of Development Economics 62: 385-421. [CrossRef]

Ray, Ranjan. 2000. Child Labor, Child Schooling, and their Interaction with Adult Labor: Empirical evidence for Peru and Pakistan. World Bank Economic Review 14: 347-67. [CrossRef]

Reinsberg, Bernhard, Thomas Stubbs, Alexander Kentikelenis, and Lawrence King. 2019. The Political Economy of Labor Market Deregulation during IMF Interventions. International Interactions 45: 532-59. [CrossRef]

Rickard, Stephanie J., and Teri L. Caraway. 2019. International Demands for Austerity: Examining the Impact of the IMF on the Public Sector. Review of International Organizations 14: 35-57. [CrossRef]

Rodrik, Dani. 2012. The Globalization Paradox: Democracy and the Future of the World Economy. New York: W. W. Norton \& Company.

Rosenzweig, Mark R. 1981. Household and Non-household Activities of Youths: Issues of Modelling, Data and Estimation Strategies. In Child Work, Poverty and Underdevelopment. Edited by Gerry Rodgers and Guy Standing. Geneva: International Labour Office.

Rossi, Maria C., and Furio C. Rosati. 2007. Impact of School Quality on Child Labor and School Attendance: The Case of CONAFE Compensatory Education Program in Mexico. Understanding Children's Work Programme Working Paper, February. Rome: University of Rome.

Rowden, Rick. 2008. Blocking Progress: The IMF and HIV/AIDS. Global Social Policy 8: 19-24. [CrossRef]

Rowden, Rick. 2013. The Deadly Ideas of Neoliberalism: How the IMF Has Undermined Public Health and the Fight against AIDS. London: Zed Books Ltd.

Rudra, Nita. 2008. Globalization and the Race to the Bottom in Developing Countries: Who Really Gets Hurt? New York: Cambridge University Press.

Ruggie, John Gerard. 1982. International Regimes, Transactions, and Change: Embedded Liberalism in the Postwar Economic Order. International Organization 36: 379-415. [CrossRef]

Sachs, Jeffrey D., and Andrew Warner. 1995. Economic Reform and the Process of Global Integration. Brookings Papers on Economic Activity 1995: 1-118. [CrossRef] 
Salinas, Gonzalo, and Ataman Aksoy. 2006. Growth Before and after Trade Liberalization. World Bank Policy Research Working Paper No. 4062. Washington, DC: World Bank.

Schultz, Theodore W. 1960. Capital Formation by Education. Journal of Political Economy 68: 571-83. [CrossRef]

Schultz, Theodore W. 1961. Investment in Human Capital. The American Economic Review 51: 1-17.

Shenk, Mary K., Mary C. Towner, Howard C. Kress, and Nurul Alam. 2013. A Model Comparison Approach Shows Stronger Support for Economic Models of Fertility Decline. Proceedings of the National Academy of Sciences USA 110: 8045-50. [CrossRef]

Simmons, Beth A. 2000. International Law and State Behavior: Commitment and Compliance in International Monetary Affairs. American Political Science Review 94: 819-35. [CrossRef]

Stiglitz, Joseph E. 2002. Globalization and its Discontents. New York: Norton, vol. 500.

Stubbs, Thomas, and Alexander Kentikelenis. 2017. International Financial Institutions and Human Rights: Implications for Public Health. Public Health Reviews 38: 1-17. [CrossRef] [PubMed]

Stubbs, Thomas, and Alexander Kentikelenis. 2018. Targeted Social Safeguards in the Age of Universal Social Protection: The IMF and Health Systems of Low-income Countries. Critical Public Health 28: 132-9. [CrossRef]

Stubbs, Thomas, Bernhard Reinsberg, Alexander Kentikelenis, and Lawrence King. 2020. How to Evaluate the Effects of IMF Conditionality. Review of International Organizations 15: 29-73. [CrossRef]

Stuckler, David, Lawrence P. King, and Sanjay Basu. 2008. International Monetary Fund Programs and Tuberculosis Outcomes in Post-communist Countries. PLoS Medicine 5: 1079-90. [CrossRef]

Tomz, Michael. 2012. Reputation and International Cooperation: Sovereign Debt across Three Centuries. Princeton: Princeton University Press.

Vamvakidis, Athanasios. 1999. Regional Trade Agreements or Broad Liberalization: Which Path Leads to Faster Growth? IMF Staff Papers 46: 42-68.

Vreeland, James Raymond. 2002. The Effect of IMF Programs on Labor. World Development 30: 121-39. [CrossRef]

Vreeland, James Raymond. 2003. The IMF and Economic Development. New York: Cambridge University Press.

Vreeland, James R. 2006. IMF Program Compliance: Aggregate Index versus Policy Specific Research Strategies. Review of International Organizations 1: 359-78. [CrossRef]

Wacziarg, Romain, and Karen Horn Welch. 2008. Trade Liberalization and Growth: New Evidence. World Bank Economic Review 22: 187-231. [CrossRef]

Walter, Stefanie. 2017. Globalization and the Demand-Side of Politics: How Globalization Shapes Labor Market Risk Perceptions and Policy Preferences. Political Science Research and Methods 5: 55-80. [CrossRef]

Whoriskey, Peter, Rachel Siegel, and Salwan Georges. 2019. Cocoa's Child Laborers. Washington, DC: The Washington Post.

World Bank. 2020. World Development Indicators. Washington, DC: World Bank Group.

World Health Organization. 2014. The Health of the People: What Works—the African Regional Health Report 2014. Brazzaville: WHO Regional Office for Africa.

World Trade Organization. 2019. Labour Standards: Consensus, Coherence and Controversy. In Understanding the WTO: Cross-cutting and New Issues. Washington: World Trade Organization. Available online: https:/ /www.wto.org/english/thewto_e/whatis_e/ tif_e/bey5_e.htm (accessed on 30 August 2020). 